ARTICLE OPEN

\title{
Sustainable Development in Rural Areas of Mexico through Beekeeping
}

\author{
Giuliana Vinci*, Mattia Rapa and Federico Roscioli \\ Department of Management, Sapienza Univeristy of Rome, via del Castro Laureziano 9, 00161 Rome, Italy \\ Emailid: giuliana.vinci@uniroma1.it,mattia.rapa@uniroma1.it, federico.roscioli@gmail.com
}

\begin{abstract}
A holistic approach that includes social cohesion, accessibility to means of production, policies and nutritional education is widely recognized as needed to fight food insecurity in the world. By investigating the surprising achievements of the Heifer International projects in the rural areas of Mexican states such as Veracruz and Chiapas, this article advances the theory of a multiplier effect given by beekeeping if inserted in a wider food and economic security project. Beekeeping is not only functional as integrator of family income in rural families, but it also provides a healthy sugar source, environmental sensitisation, women empowerment, social cohesion and lots of sub-products for healthcare and cosmetics. Such a huge impact on families has, in fact, to be added to the general positive impact of beekeeping on biodiversity and climate change. The introduction gives a review of the concept of food and economic security for rural families. The second part portraits the complexity and inequality of Mexico in both its economic and nutritional environment. In the last part the Heifer International project structure and goals are explained, followed by an analysis of the data collected as well as an illustration of the impact of this project over the economy, the society and the environment.
\end{abstract}

Keywords: development, sustainable development, Mexico, beekeeping.

\section{INTRODUCTION}

We can introduce the concept of food security as the 'entitlement' "to the access to food enjoyed by a household by virtue of its socially recognised right to control certain resources" (Sen, 1981). The resources on which the entitlement is based may vary; they could be a cash entitlement that enables people to buy an adequate supply of food if available, or the ownership of their land and labour for subsistence farmers (Millman \& Kates, 1990). This year the positive trend of the estimation of chronically undernourished people in the world has seen a drastic negative change. According to FAO's latest report on the state of food and agriculture, this change has been caused by the higher number of shocks due to human and climate causes and the increasing in-country inequality, particularly in subSaharan Africa and South Asia (Nawrotzki et al., 2016). Most of these countries have some common factors: economies with large shares of employment in agriculture, hunger, malnutrition, uncontrolled urbanisation and high levels of poverty. The latest estimations shows that in low-income and lower-middle-income countries around 1.75 billion people survive with less than US\$ 3.10 a day, and more than 580 million are chronically undernourished(Barrett, 2010).

A major force behind inclusive rural transformation would be the growing demand coming from urban food markets, which consume up to 70 per cent of food supplies even in countries with large rural populations (FAO, 2017). Urbanization, in fact, provides a golden opportunity for agriculture. At the same time, increased levels of urbanization present challenges for millions small-scale family farmers. Poor subsistence farmers, for instance, have moved from rural areas to the streets of the new populous metropolitan cities (Haer et al., 2018). Moreover, the subsequent loss of entitlements by these people - mostly land property - contributed to increase inequality levels inside these new urban agglomerates. In this case, the Nurkse 's vicious cycle of poverty applies to these new poor: they are poor because they are poor, and they are too poor to get out of this situation (Nurkse, 1953). Poverty without entitlements leads to food insecurity and undernourishment, which in turn leads to a lack of physical and mental development as well as to low productivity (Martin and Ferris, 2007). What sub-Saharan Africa and South Asia are facing today also occurred in Latin America in the past, when industrialization and the use of capitalintensive production in rural areas were linked to the rapid urbanization and the concentration of urban population in larger cities (FAO, 2017:9). The higher level of urbanization reached was a major determinant of agricultural policies directed to ensure low food prices in urban areas. In rural areas production was, and still is today, warranted by a high number of small farms and a lower number of medium and large commercial farms. Land tenure structure, however, became more and more concentrated (Anríquez, Foster and Valdés, 2017). The Latin America path guaranteed the decrease of food insecure people in the short run, but it increased the level of inequality and poverty perception by the majority of the population in the long one.

Urbanization is also linked to the shift from an almost exclusive consumption of raw food to minimally processed, highly processed and super nutritious food (Nygren, 2018). Researches show that processed food had penetrated into both African and Asian diets, with a particularly high effect on Asian urban people. Almost two-thirds of the food budget among the 
urban and rural poor in Eastern and Southern Africa are dedicated to processed food (Tschirley et al., 2015b). In fact, those attempts to limit food costs will first select less expensive but more energy-dense foods to maintain energy intake, and if food costs for processed products further diminish, then the total energy intakes may actually increase. (Drewnowski \& Spencer, 2004). Energy density of foods is the key factor on daily energy intakes (Drewnowski, 1998:56, 347-53; Prentice, 1996:20 (suppl), S18-23). We can use the words of Ezzeddine Boutrif, Director of the FAO Nutrition and Consumer Protection Division: "it is not only the amount of food, also the quality of a diet has a critical effect on children's growth, health and learning capacity. Eating is not just a biological process, it depends on learned habits and perceptions and on the cultural and social environment. This is why nutrition education is so important" (Friedmann, 2017).

Diet changes are also visible when income rises in the developing world and there is a shift from cereals and tubers to meat, fats and sugar (Keats and Wiggins, 2014). Data says that over one-third of all adults across the world are obese or overweight. In developing countries, between 1980 and 2008, the number of people overweight more than tripled and in highincome countries the number almost doubled over the same period (Keats and Wiggins, 2014). Overweight and obesity are now on the rise everywhere, particularly in urban settings, even if once these were considered a high-income country problem (OMS, 2017). We can, then, state that obesity and undernourishment constitute the double burden of malnutrition.

Through its effects on health, malnutrition increases health-care costs, reduces productivity and slows economic growth, which can trigger a cycle of poverty and ill-health (Figure 1). The direct and indirect costs of this problem are often unsustainable and contribute to the creation of a significant barrier to economic and social development (WHO, 2016).

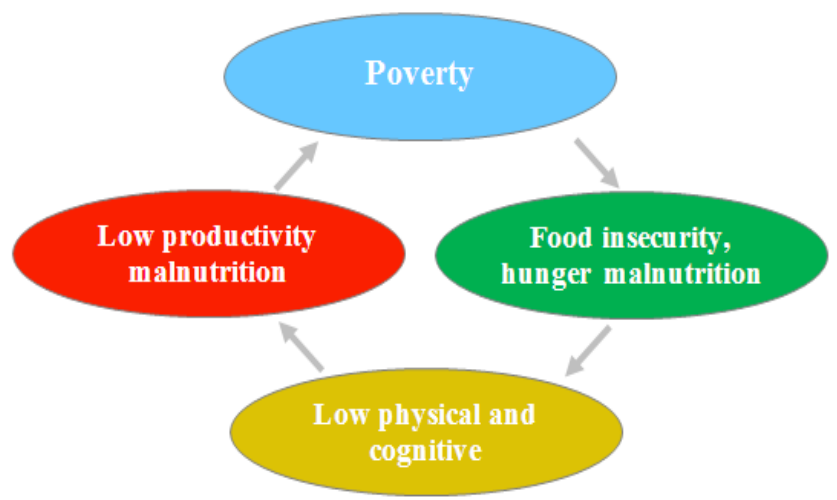

Figure 1: Vicious cycle of poverty

The first approach to resolve the food insecurity issue was a quantitative approach that boosted production and lowered prices, as we have previously noticed for Latin America. This happened between 1960 and 1980 and it was promoted by the international community as "the Green Revolution". As of today, we see its effects on farming starting from the USA and then spreading all over the world. In fact, thanks to the use of chemical fertilizers, pesticides, herbicides and chemical-resistant and more productive seeds, the Green Revolution has been able to double the food production of many crops (Dinour et al., 2007). This miraculous result was also connected to a high and well recognized cost. It was, as a matter of fact, a policy that was only empowering richer farmers, due to its expensive production factors, and today it is acknowledged that the increase in food production alone does not affect rural food insecurity and poverty (Chambers e Ghildyal, 1985; Pearse, 1980). A monopolistic market has been created by the Green Revolution: back in 2008, the top ten agrochemical corporations controlled almost 90 per cent of the global sales of pesticides, and out of the US\$22 billion global proprietary seed market, only ten corporations controlled 67 per cent of it (Phillips, 2013). These trends across the food industry have been on an almoststeady climb since they were first recorded in the 1970s (US Agriculture, 2012). Moreover, this industrial agricultural system contributes to about half of the global greenhouse gas emissions, including not only the farming part of agriculture, such as plowing and fertilizing, but also emissions from land-use change and deforestation, as well as the processing, packaging, transport and sale of agricultural products (Grain, 2014).

The capacity of families to ensure an adequate supply of food for their members is undoubtedly constrained by local and global developments (McKeon, 2015:3). Even if they are producing 70 per cent of the food consumed in the world, unprotected smallscale producers are being driven off their land and out of their markets because of the allegation that they are inefficient and archaic.

A different approach was proposed in 1996 by Via Campesina, an international network of peasant organizations.

Instead of food security, Via Campesina has advocated for "food sovereignty" claiming that: "communities have the right to define their own food and agriculture policy" (Patel, 2009:36, 663$673)$. Sovereignty, then, is not meant to be a call for states to grow sufficient food to feed their citizens within their borders, but a wish for people to be sovereign over their food systems and have the power to decide what the system should look like. It is through food sovereignty, Via Campesina argues, that food security might be achieved and undernourishment eradicated (Patel, 2012). Lastly, joint forces of the United Nations and civil society agreed to this point as well, as Oliver De Schutter, Special Rapporteur on the right to food for UN, stated: "The deeper debate concerns not whether productivity should be raised, but how to achieve this. Increasing yields alone will not do. Any prescription to increase yields that ignores the need to transition to sustainable production and consumption, and to reduce rural poverty, will not only be incomplete, it may also have damaging impacts, worsening the ecological crisis and widening the gap between different categories of food producers." (De Schutter, 2014b:8).

In conclusion we can state that that civil society is asking more and more so that agriculture can return to be what it was: an embedded, connected and localized activity largely serving and being served by its city regions (Marsden, 2012:259).

\section{IN-COUNTRY INEQUALITY, MEXICO}

Mexico, being the second economic power of Latin America and 15th at world level, is considered an upper middle-income country (World Bank, 2016-17) (Figure 2), but it is also at the 19th place in the Gini Index ranking for inequality, close to poor countries like Honduras, Guatemala and Rwanda (World Bank, 2017). Mexico's economy is based on extractive, vehicles and communication industries, but also on an agricultural system focused on cereal production (mainly corn) (de Blanco et al., 2014). 90 per cent of the goods exported are directed to the United States of America (Newsham et al., 2018). The amount of exports has more than quadruplicated since the signing of the North American Free Trade Agreement (NAFTA) in 1994 (World Development Indicators, 2016). 


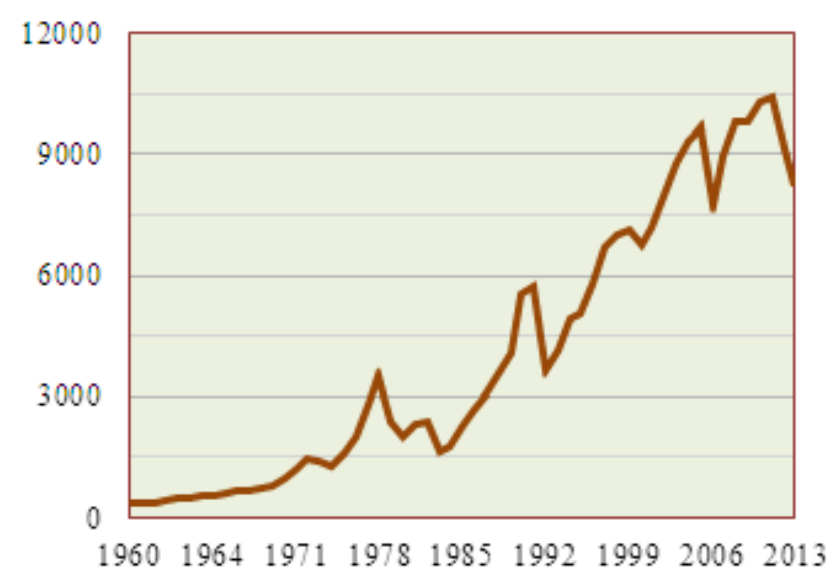

Figure 2: Mexico gdp per capita (current us\$) (world development indicators, 2016)

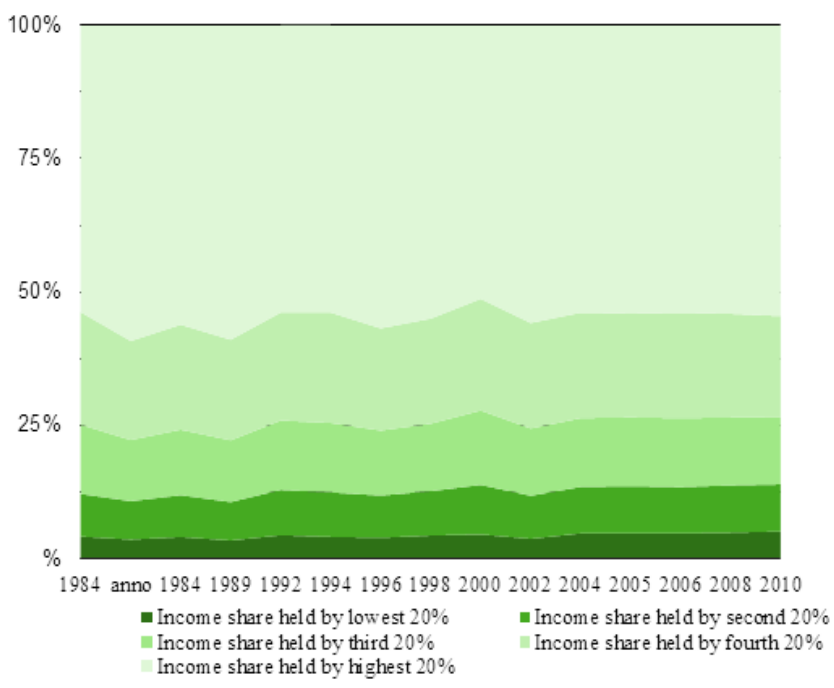

Figure 3: Mexican income share (world development indicators 2010)

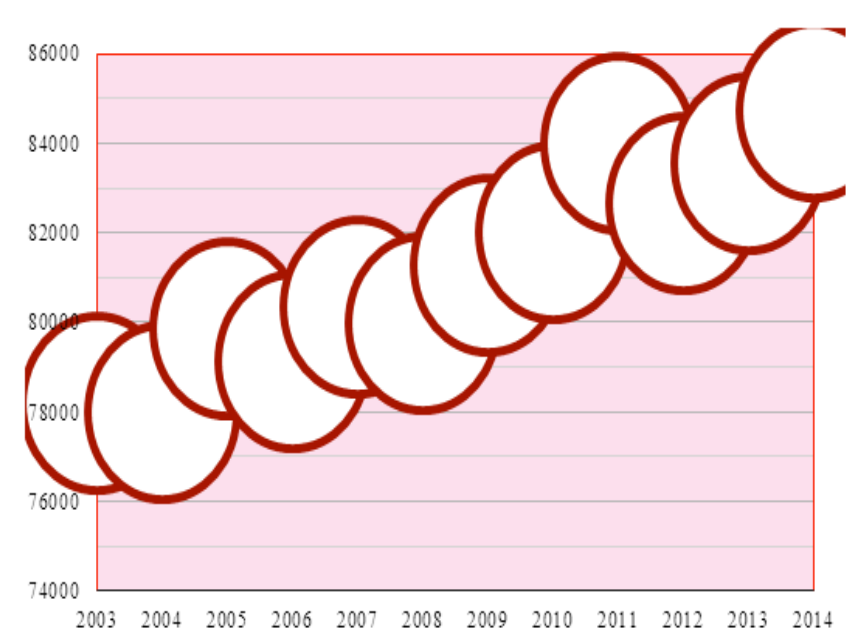

Figure 4: Total emissions of agricultural sector (co2 equivalent) (faostat, 2016)

Despite a stable economic growth in the last fifty years (Figure 3 ), we can clearly see on Figure 2 how the income is differently distributed through the population. In fact, in the last thirty years the highest 20 per cent of the population held stably around 55 per cent of the whole income (Cuevas-nasu et al., 2018). On the rural area of Mexico we can observe two apparently contradictory tendencies, that, in reality, show the proof of the effects of the Green Revolution in the country: since 1950,
Mexico's population density increased almost seven-fold (World Population Prospects: The 2017 Revision) due to the urbanization trend; at the same time, there was a quadruplication of crop production, accompanied by an increased area dedicated to agricultural land, pastures and use of synthetic fertilizers, pesticides, herbicides (Faostat, 2016). This clear shift in direction of a more industrialized agriculture sector was needed, particularly after the stipulation of the NAFTA agreement, in order to satisfy Mexican economic partners and the new urban population. This development has also been accompanied by an increase of $\mathrm{CO} 2$ emissions (Carbon Dioxide Information Analysis Center, 2014), predominantly in the agricultural sector (Figure 4), highly contributing to climate change (Rosen and Guenther, 2015).

Data on the assimilation of energy from food show how this increase of food production did not have a positive effect on the quality of the Mexican diet: today, as a matter of fact, 45 per cent of their energy intake comes from cereals (mostly corn), 15 per cent from sweeteners (out of which 70 per cent comes from sweet beverages) and 9 per cent from vegetable oils, with a higher disequilibrium in rural areas of the country (CruzDomínguez et al., 2017; Shamah-Levy et al., 2017).

\section{MALNUTRITION AND POVERTY IN RURAL AREA}

The rural areas of Mexico are where inequality is more evident. Mexico classified 2nd in the world for the Happy Planet Index of 2016 and 71st in Human Development Index 2014, but if we compare the same indexes for the single states of Mexico, we see that, while in the Federal District we have levels similar to Germany, in more rural states like Chiapas, Oaxaca, Veracruz, the indexes are similar to those of Burundi and Kenya (Ricks, 2017). In these areas, chronic child malnutrition is at 13.6 per cent, with peaks of 27.5 per cent in rural and indigenous areas of the South-East of the country. Moreover, only 14.4 per cent of newborns receive breast-feeding in the first six months of life (UNICEF annual informative, 2013).

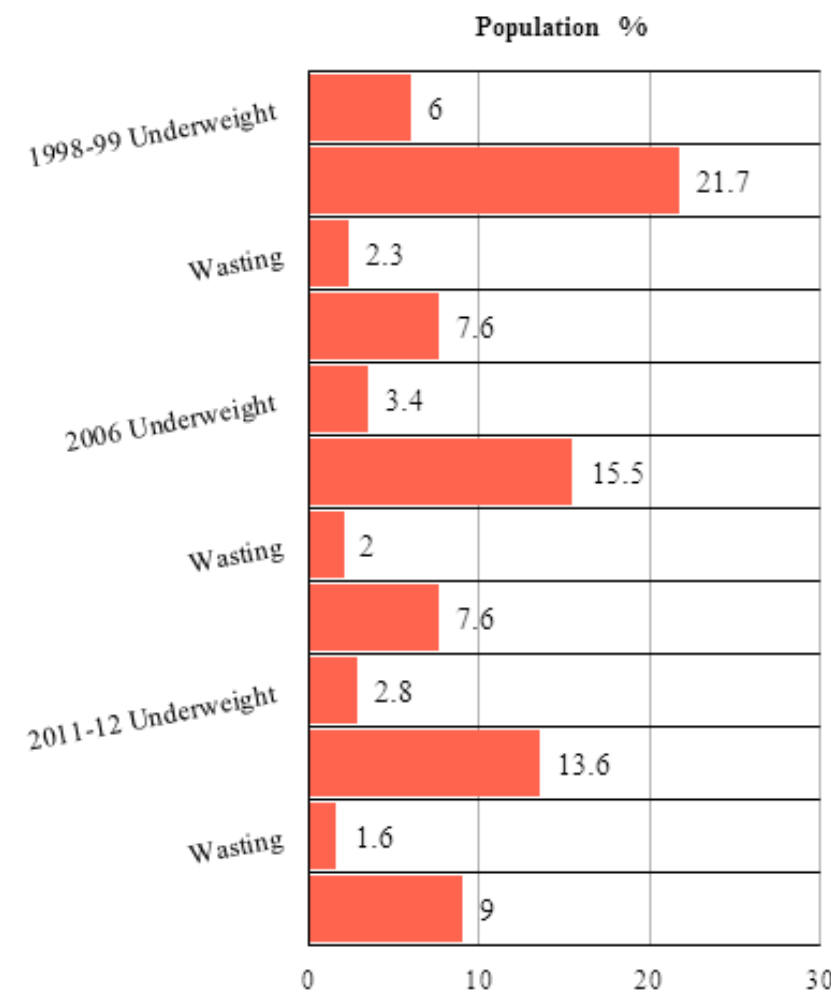

Figure 5: Child malnutrition estimates (world health organization 2015) 


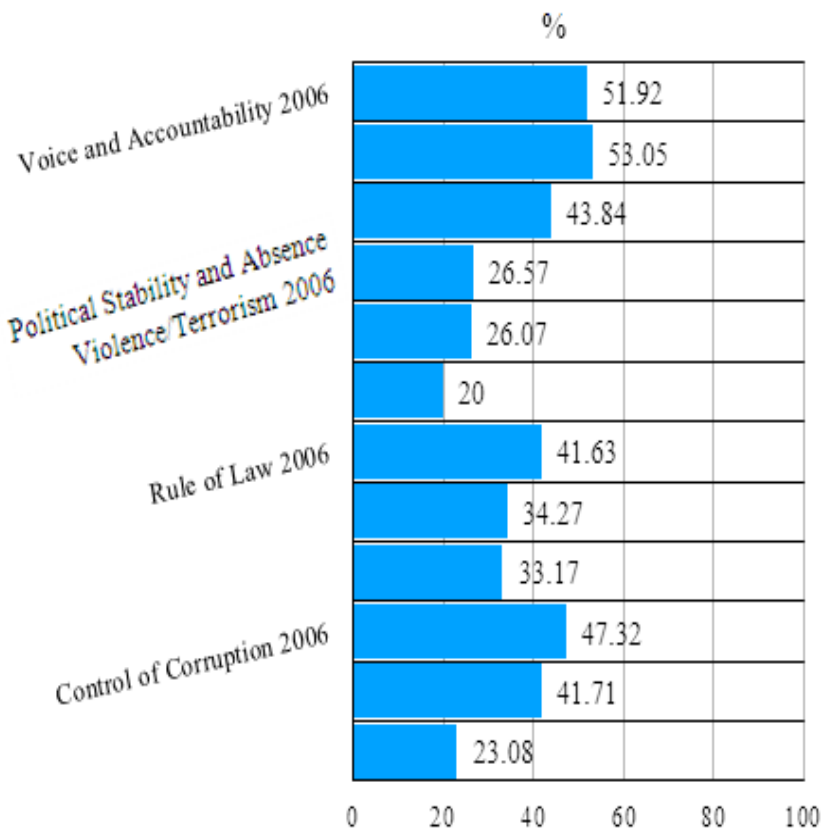

Figure 6: Quality of institutions in mexico (kaufmann d., a. Kraay, and $\mathrm{m}$. Mastruzzi (2010), the worldwide governance indicators: methodology and analytical issues)

FAO data confirms that in rural and mountain areas around half of the population is vulnerable to hunger (Figure 5). More specifically, 72 per cent of the population is in a state of poverty or vulnerability to external contingencies (Hardy, 2014: 32) and 11 per cent lives with less than US\$ 3.10 per day (World Bank, 2015). Children living in the South-East of the country and in indigenous areas are those who are more affected by this social and economic iniquity. In states like Oaxaca or Chiapas there is a child mortality rate of 20 per cent, while in Guerrero maternal mortality is at 76 per cent. This data gives us a portrait of inequality and poverty in which food insecurity is mainly caused by the rapid loss of public support, rights and public investment since 1970, when the 60 years long land reform ended. This is also confirmed by World Bank indicators on institution quality, in the last ten years (Figure 6).

In the last decades, these rural and indigenous groups have seen and experimented many projects of investment driven by the private sector, particularly by multinational companies looking to exploit the huge amount of resources present in the territory. An example can be taken from the Coca-Cola investments in Chiapas, which owns about thirty percent of Mexico's fresh water resources. Since 1994, Coca-Cola FEMSA established many bottling plans in this state claiming to bring jobs and investment to the area, which in fact happened, but at what cost? The uncontrolled and low-cost exploitation of water by the plants let many communities without this vital liquid (Martha Pskowski, 2017). At the same time, schools and social projects funded by the company were used to advertise the Coca-Cola brand in these same poor communities. This example is emblematic if we think that in 2013 Mexico was the first country in the world in the sale of sugar-sweetened beverages - with 163 litres per person - and for overweight adults. From data collected in the National Enquiry for Nutrition, it emerges that stunting and underweight children are strongly decreasing, but overweight children are, at the same time, unfortunately increasing. Chiapas, being one of the poorest states of Mexico, is one of the highest consumers of these kind of sugar-sweetened beverages.

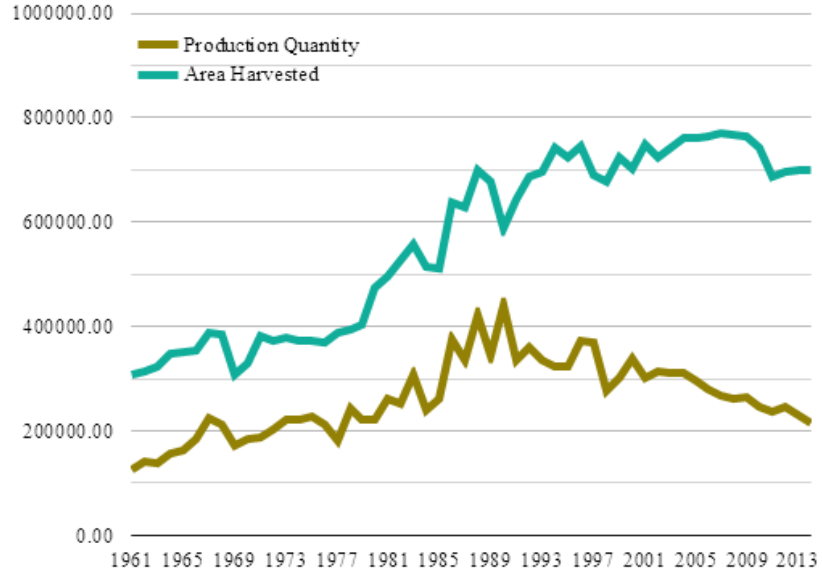

Figure 7: Coffee production in mexico (faostat, 2016)

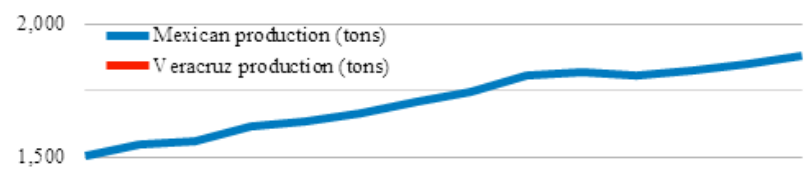

1,000

500

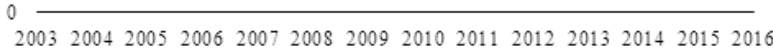

Figure 8: Bovine meat production (siap 2016)

\section{RESULTS AND DISCUSSION:}

\section{THE CHIAPAS AND VERACRUZ CASE STUDIES \\ CHIAPAS COFFEE PRODUCTION}

Chiapas is the first producer of coffee of the country, in particular on the mountain area of Sierra Madre. The production mainly comes from small farmers linked, through cooperatives, to important buyers. Chiapas' climate varies mostly between hothumid and sub-humid areas. Coffee production in this area is the main and only income source for many rural families and its dropping trend (half of the production lost in the last 20 years) is dramatically affecting food security in the households (Figure 7). The roya, or coffee rust, is the main culpable for this trend. It is an illness that first appeared in 1981 in Southern Mexico and Guatemala but started expanding in the last ten years killing a large part of the plantations. Since the coffee rust prospers in highly humid climates, its effect rose during the last few years due to the increase of global temperature, rains and number of hurricanes.

The first response to this production problem came from the coffee business, suggesting the use of a non-autochthon seed. The new seed is mysteriously unaffected by the rust (it cannot be a GMO, because in Mexico its use is forbidden), but it needs to be planted under the sun and needs fertilisers, as the old seed grew perfectly in this mountain and forest area. This meant deforestation, higher use of chemicals and also an increased plantation exposure to high-impact climate events, where covered coffee plantations are found to be more resilient in these extreme cases. 
Alternative ways of adaptation follow a diversified production, implementing other crops like chayote and bananas, but also apiculture. Beekeeping is in fact at the center of the Heifer International project that we will analyse further. Through beekeeping, Heifer was able to implement a new source of income for the families, also increasing women empowerment, social cohesion, environmental sensitisation and a long list of healthy and safe sub products of honey useful in these rural areas.

\section{VERACRUZ BOVINE MEAT PRODUCTION}

The state of Veracruz is the first producer of bovine meat in Mexico, making up more or less 14 per cent of national production (Figure 8). Bovine meat production in Mexico increased three times in the last 13 years: this meant a drastic change in land use, from forest to agriculture and pastures. In fact, in Veracruz only the natural vegetation went from 31 per cent per cent in 1976 to 19 per cent in 2011 (data from INEGI). Livestock production has a huge impact over climate change, not only because of deforesting and implicating a loss of biodiversity, but also because of increasing by a huge amount of CO2 emissions (Carlsson-Kanyama \& D González, 2009). In the province of Coatzacoalcos, where the Heifer project was implemented, climate change has shown its harsher results. The deforestation of both forests and mangroves left vast areas unprotected from disruptive climate events: in 2005, for instance, hurricane Stan destroyed almost everything, leaving entire families without food and housing. Despite what happened, bovine meat production is still trusted to be the best investment in the region because of its high remuneration rates in the short run, with no consideration of its environment impact(Kaiser et al., 2003). The group of families involved in the beekeeping project was not only able to recover from poverty in a sustainable way but was also able to activate some strong side environmental projects aimed to improve the climate change impact of the area.

\section{THE HEIFER INTERNATIONAL PROJECT “A SWEET TRIUMPH"}

The Heifer International project assisted 445 families between 2010 and 2015 focusing on the principles of food sovereignty by providing farm animals, seeds, technical equipment and training in order to offer an independent and durable change for these small farmers and their communities. The key points developed by Heifer in its Mexican projects are: women empowerment through exclusive women groups and full participation in mixed projects; pro capita income increase through diversification of production and access to new markets; human and social capital improvement thanks to professional training, the use of "farmer to farmer" practice and the institution of cooperatives; nutritional improvement thanks to the diversified production implemented; environmental sensitisation through parallel projects focused on conservation, agroforestry and agroecology.

The use of "passing the gift", or "farmer to farmer", in particular, had an important effect over the replicability and spread of the means that Heifer made available for the participants. This pedagogic farming practice comes from the Farmer to Farmer Movement born in 1972 in Guatemala, it is focused on sharing knowledges and experiences aimed to increase local strength and problem-solving capacity inside a horizontal relationship between farmers. The new and free of charge improved strength at the local level is then able to overcome the possible lack of dedicated policies of the state. Gift economies have also proved to be able to prevent and restrain the effects of food crises and famine in realities in which the state organization is weak or inefficient (Swift, 1993). More in detail, this model consists of the obligation for the recipients of Heifer facilitations to freely hand down at least the same amount of means and knowledge that they received (Ángel Magaña Magaña et al., 2017).

Another fundamental aspect of the project was the use of beekeeping as an alternative or complementary source of income for small farmers. Beekeeping proved to be economically and environmentally sustainable. In fact, honey production does not require a lot of time, so it allows farmers to keep working on their main activities; the cost of beekeeping inputs is either fixed (technical instruments, wooden apiary and wax) or tend to zero (water with sugar only during some particular seasons); the management of an apiary is not a heavy job, so this offers possibilities for women to enter the farming market by themselves or together with men. Moreover, an apiary not only produces honey, but also important side products for healthcare and cosmetics that can be put in the market like royal jelly, pollen, propolis, wax, etc... It also helps with improving pollination and biodiversity both in natural and cultivated environments, contributing to additional agricultural gains (Güemes-Ricalde et al., 2006).

\section{ECONOMIC CHANGE}

In five years the project was able to increase honey production for the participating farmers by 155,3 per cent from a total of 18,8 tons in 2010 to 48 tons in 2015 (Figure 9). This huge improvement was due to gained skills and technical methods learned from Heifer experts and consultants and the subsequent increased productivity per apiary (Pröpper, 2015). The augmented production also influenced an improvement in income. In fact, market access initially given by a local collector was later on substituted by a stockiest firm, with a consequent 5 per cent profit improvement over the local price. This improvement was only achievable thanks to the gained strength by the union in cooperatives (Leyer, 2018).

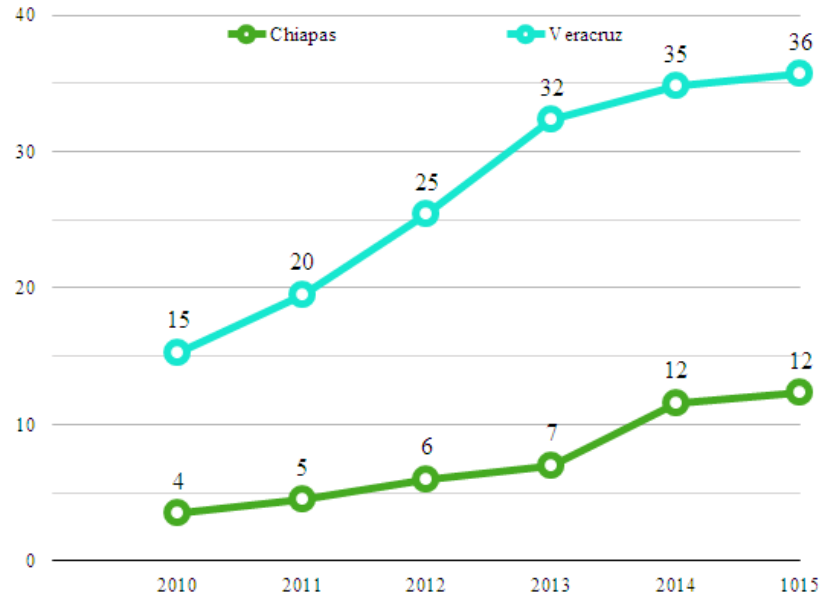

Figure 9: Annual honey production (tons) inside heifer project (heifer, 2015)

\begin{tabular}{c|c|c|c}
\hline & Jan - Jun 2015 & Jul - Dec 2015 & Total \\
\hline Printed Wax (kg) & 335 & 107,5 & 442,5 \\
\hline Nucleus Queens & 528 & 183 & 711 \\
\hline Pollen (kg) & 5,8 & 1,105 & 6,905 \\
\hline Propolis (kg) & 3.6 & 4,623 & 18.03 \\
\hline Royal Jelly (g) & 320 & 316 & 636 \\
\hline
\end{tabular}

Figure 10: Honey sub-products production (heifer 2015)

From 2013 to 2015 Chiapas families, in almost every case, saw the annual income coming from beekeeping double up, reaching 
around US\$ 526.68, compared to the average annual GDP per capita of US\$ 427.00 (OECD, 2010). In the same period Veracruz families, involved in the project, increased their annual income from beekeeping by 40 per cent, reaching around US $\$$ 2,175.14 (Heifer International, 2015), compared to the average annual GDP per capita of US\$2,713.46 (OECD, 2010). In both cases, this meant being able to double their household income. Moreover, the sale of bee-related products like wax, nucleus, pollen, propolis and royal jelly was an additional source of income (Figure 10) (Sathyamala, 2016).

\section{SOCIAL AND ENVIRONMENTAL CHANGE}

Women inclusion was important. Many women were able to manage an apiary by themselves or work together with their husbands and produce more than 500 different sub-products for healthcare and cosmetics, being finally able to be independent or at least to contribute to the household income ( $\mathrm{He}$ et al., 2017).

As previously stated, the cooperative played a key role in gaining contractual power with the distributor firm, but they also contributed to an improvement in social cohesion both incommunity and between nearby communities. Cohesion has not only to be intended as "working together", but also as the ability to replicate the project through the farmer to farmer model, and doing so by helping those with less economic capability to enter in the business, elevating them to the same social status level. Interviewed participants stated that the perfect cohesion shown by the bees was also as an example of how humans should act between themselves (Barquera et al., 2013).

Finally, bees care boosted environmental sensitisation in participant communities. In fact, in order to prosper, bees need a natural and safe environment, without chemical contamination and with as much variety of vegetation as possible. This need led to parallel environmental projects, such as mangrove, pastures and oyster bank reforestation, and an additional care about the status of the vegetation in the area. In addition, in Veracruz, the cooperative was able to rescue a particular native bee without sting, one under threat of extinction, and started to breed it inside the house courtyard, selling its special honey.

\section{CONCLUSIONS}

We can then state, that diversified income sources increase the resilience of small farmers in case of emergency due to human or natural catastrophes, but there is more to it. In fact, beekeeping is not just a mere income source. Beekeeping implies the inclusion of a vast number of factors that positively affect not only the income, but also the environment, women empowerment, social cohesion and the wealth of the people involved. Beekeeping should therefore be considered a sort of multiplier effect over the results of a wider project that involves food security in rural areas, due to its multileveled influence on all the aspects of the project (economic, social and environmental).

Beekeeping is not the universal solution for food and economic security in rural areas, but it has proven to be a key instrument in wider and more complex projects covering this issue. It has also proved to have a good capacity of adaptation in different climate areas, such as the coastal tropical climate of Veracruz and the high mountain climate of Chiapas.

Of course, the Heifer project is just a small drop in a vast and unequal country like Mexico, but the State could oversee the project at a sectoral level, evaluate its impact and implement it inside its ongoing Project on Food Security in Rural Area (PESA). An institutional implementation would guarantee an increased social protection for these rural families, a safe and sustainable market to work with, and a contribution in the reduction of the climate change impact of the agricultural sector. All of this with a cost that is really minimal, thanks to the use of the farmer to farmer model that enables a free of charge replicability of the instruments.

\section{REFERENCES}

[1] Carlsson-Kanyama A.; González A.D., "Effect of plantbased dietary choices on the environment: Potential contributions of food consumption patterns to climate change", Am J Clin Nutr 2009 89: 5 1704S-1709S. 2009.

[2] Ángel Magaña Magaña, M., J. Roberto Sanginés García, P. Enrique Lara Lara, L. de Lourdes Salazar Barrientos, and C. Enrique Leyva Morales,"Competitividad y Participación de La Miel Mexicana En El Mercado Mundial Competitiveness and Participation of Mexican Honey in the World Market', Rev Mex Cienc Pecu 8(1): 43-52, 2017.

[3] Barquera, S., I. Campos-Nonato, L. HernándezBarrera, A. Pedroza, and J. a. Rivera-Dommarco, "Prevalencia de Obesidad En Adultos Mexicanos 2000-2012', Salud Pública de México 55(.2): 151-60. 2013.

[4] Barrett, C.B., "Measuring Food Insecurity", Science 327(5967): 825-8. 2010.

[5] de Blanco, M.L., M. Landaeta-Jiménez, M.H. Cuenca, and Y. Sifontes, "The Double Burden of Undernutrition and Obesity in Venezuela ", Anales Venezolanos de Nutricion 27(1): 77-87. 2014.

[6] Cruz-Domínguez, M.P. et al., "Malnutrition is an Independent Risk Factor for Mortality in Mexican Patients with Systemic Sclerosis: A Cohort Study", Rheumatology International 37(7): 1101-9. 2017.

[7] Cuevas-nasu, L. et al.,"Tendencias de La Mala Nutrición En Menores de Cinco Años En México, 1988-2016: Análisis de Cinco Encuestas Nacionales" 60(3): 283-90. 2018.

[8] Dinour, L.M., D. Bergen, and M.C. Yeh , "The Food Insecurity-Obesity Paradox: A Review of the Literature and the Role Food Stamps May Play", Journal of the American Dietetic Association 107(11): 1952-61. 2007.

[9] Drewnowski \& Spencer, "Poverty and obesity: the role of energy density and energy costs." Am J Clin Nutr. 2004 Jan; 79 (1):6-16. 2004.

[10] Encuesta nacional de nutrición, Tomo 1: Resultados, niños menores de 5 años. Instituto Nacional de Salud Publica. Cuernavaca, Mexico. 2000 (and additional analysis).

[11] FAO (2017) "The State of Food and Agriculture 2017 Leveraging food systems for inclusive rural transformation".

[12] Friedmann, H., "Paradox of Transition: Two Reports on How to Move Towards Sustainable Food Systems", Development and Change 48(5): 1210-26. 2017.

[13] Güemes-Ricalde, F.J., R. Villanueva-G, C. Echazarreta-González, R. Gómez-Alvarez, and J.M. Pat-Fernández, "Production Costs of Conventional and Organic Honey in the Yucatán Peninsula of Mexico", Journal of Apicultural Research 45(3): 106-11. 2006.

[14] Haer, T. et al.,"Subject Areas: Coastal and River Flood Risk Analyses for Guiding Economically Optimal 
Flood Adaptation Policies: A Country-Scale Study for Mexico", Philosophical Transactions of the Royal Society A: Mathematical, Physical and Engineering Sciences 376(2121). 2018.

[15] He, C., Q. Han, B. de veris, X. Wang, and Z. Guochao, "Evaluation of Sustainable Land Management in Urban Area: A Case Study of Shanghai, China", Ecological Indicators 80(April): 106-13. 2017.

[16] Kaiser, L.L. et al., "Food Insecurity and Food Supplies in Latino Households with Young Children", Journal of Nutrition Education and Behavior 35(3): 148-53. 2003.

[17] Keats and Wiggins, "Future diets: Implications for agriculture and food prices". 2004.

[18] Martha Pskowski "Coca-Cola Sucks Wells Dry in Chiapas, Forcing Residents to Buy Water". Truthout. 2017.

[19] Leyer, R.V., "Aiming to Keep Poor Mexican Families at the Breadline (but No Higher): The Effects of Minimum Wage, Tax, and Social Policy Changes between 1994 and 2012'(May 2017): 1-18. 2018.

[20] Martin, K.S. and A.M. Ferris, "Food Insecurity and Gender Are Risk Factors for Obesity", Journal of Nutrition Education and Behavior 39(1): 31-6. 2007.

[21] Hendrickson M., Harvey S.J., Heffernan W.D, "Vertical integration and concentration in US agriculture", Encyclopedia of food and agricultural ethics:17991806. 2014.

[22] Lucile F. Newman et al. (eds.) Hunger in history: food shortage, poverty, and deprivation. Oxford: Basil Blackwell, pp.3-24. 1990.

[23] Nora McKeon, "Food Security Governance Empowering Communities, Regulating Corporations". 2015.

[24] Nawrotzki, R.J., D.M. Runfola, L.M. Hunter, and F. Riosmena, "Domestic and International Climate Migration from Rural Mexico", Human Ecology 44(6): 687-99. 2016.

[25] Newsham, A. et al., "Ecosystems-Based Adaptation: Are We Being Conned? Evidence from Mexico", Global Environmental Change 49(July 2016): 14-26. 2018.

[26] Nurkse, Ragnar, "Problems of Capital Formation in Underdeveloped Countries." Oxford: Oxford University Press. 1953.

[27] Nygren, A., "Inequality and Interconnectivity: Urban Spaces of Justice in Mexico", Geoforum 89(October 2016): 145-54. 2018

[28] Popkin, Barry M et al., "Sweetening of the global diet, particularly beverages: patterns, trends, and policy responses." The Lancet Diabetes \& Endocrinology, Volume 4, Issue 2, 174-186. 2015.

[29] Prentice AM, Poppitt SD. "Importance of energy density and macronutrients in the regulation of energy intake" Int J Obes 20 (Suppl 2): S18-S23. 1996

[30] Pröpper, M., "Emerging Markets for Nature and Challenges for the Ecosystem Service Approach", Development and Change 46(2): 247-68. 2015.

[31] Raj Patel. "The Long Green Revolution, The Journal of Peasant Studies", 40:1, 1-63. 2013

[32] Raj Patel Guest Editor: "Food sovereignty, Journal of Peasant Studies", 36:3, 663-706. 2009

[33] Ricks, J.I.,"Sector-Specific Development and Policy Vulnerability in the Philippines", Development and Change 48(3): 567-89. 2017.

[34] Rosen, R.A. and E. Guenther, "The Economics of Mitigating Climate Change: What Can We Know?",
Technological Forecasting and Social Change 91: 93106. 2015.

[35] Sathyamala, C., "Nutritionalizing Food: A Framework for Capital Accumulation", Development and Change 47(4): 818-39. 2016.

[36] Sen A. Poverty and Famines: An Essay on Entitlement and Deprivation. Oxford: Clarendon Press. 1981.

[37] Shamah-Levy, T. et al., "Food Insecurity and MaternalChild Nutritional Status in Mexico: Cross-Sectional Analysis of the National Health and Nutrition Survey 2012", BMJ Open 7(7): 1-11. 2017.

[38] Swift, J., Understanding and Preventing Famine and Famine Mortality. IDS Bulletin, 24: 1-16. 1993.

[39] T. Mardsen, "Towards a Real Sustainable Agri-food Security and Food Policy: Beyond the Ecological Fallacies?". The Political Quarterly, 83: 139-145. 2012.

[40] Tschirley, D, Reardon, T, Dolislager, M, and Snyder, J., "The Rise of a Middle Class in East and Southern Africa: Implications for Food System Transformation". J. Int. Dev., 27, 628-646. 2015. 